\title{
4 Can poetry change the world?
}

Don't reconcile

Amal Dunqul, Don't Reconcile

With this chapter, the theme of the book shifts from the process of literary writing and socialisation to the key themes of literary imagination and engagement that we encountered in our fieldwork. Authorship also shifts, from the co-authored 'we' of Samuli and Mukhtar in the first part of the book to a single-authored 'I' of Samuli in this second part - although the we of Samuli and Mukhtar as a fieldwork team continues to participate actively in the text. We as co-authors will make one more appearance in the Afterword.

In this chapter, the first of five chapters that explore a societal and literary condition of plurality in the absence of pluralism, I ask what power literary texts could actually have in social and political conflicts and transformations. It is not about all kinds of literary text and not about all kinds of transformation. The transformation I consider is the 25 January revolution, including its long aftermath, because it was the focal event around which almost all discussions and expectations on transformation during the first year of our fieldwork circled. I look specifically at poetry, because in the immediate event of the uprising it was the most prominent literary genre, because the work of one poet in particular stood out in discussions we had around the question, and because an important discussion that I will reproduce at length later in this chapter took place among poets and focused on poetry.

When I initiated the research for this book in autumn 2010, I expected it to be a rather unpolitical project about individual engagements with literary imagination. A few months later, that changed quickly and suddenly with the 25 January revolution. When I returned to Alexandria in March 2011, everything was political. Change was in the air, and literature seemed to be part of it.

On 11 March 2011, we were invited by Zumurrod (see Chapter 1) to meet her circle of writers and literary enthusiasts. They had originally met through the online forum Rewayat (see Chapter 2), and had started to meet occasionally at a private bookshop owned by one of the members of the circle. We wanted to ask them about the motivations, grounds, and experience of writing, but instead, they were busy asking themselves how writing can change the world, and what one could write about now.

They argued that social critique was a key theme in texts they had written and read in the past years, and this gave them the feeling that what they do is 
extremely relevant - and yet they did not know what to do now. Amr Ezz Eldeen, who had written three collections of social satire, said that he had been critiquing the system in its everyday implications, but now he wanted to find ways to build something new. Others echoed this feeling, and many said they did not know what to write.

The first half of March 2011 marked the end of the original revolutionary coalition and the initial revolutionary euphoria. Less than a week after our meeting, a referendum on constitutional amendments pushed by the temporary military leadership and supported by Islamist parties resulted in the collapse of the revolutionary coalition, and was followed by increasingly antagonistic and polarising struggles. But on that day, the mood was still optimistic and unity prevailed over divisions. The writers and readers gathered in the bookshop saw change happening, and argued that any writer wants to change the world even if only to a limited extent. Echoing the mood of the day, which was summarised in the widespread slogan 'begin with yourself', they also agreed that a writer first of all changes her- or himself. The question that remained open was how. Their own uncertainty at that moment shows how open the situation appeared then, and also how busy they were with more immediate and urgent action.

Numerous writers have told us that they practically stopped working in 2011, their energies taken by more immediate and activist pursuits. Much of what was written was bound to the moment, and widely considered to be of little literary value. It should be no surprise that the most successful (more or less literary) texts that were produced in 2011 were short and blunt: slogans, poems, songs, graffiti, social media aphorisms, political satire. Only years later has a more indepth literary engagement with the revolution begun, its tone for obvious reasons much darker and more painful than the celebratory mood that prevailed during the first months.

While the revolution was not a good time to produce in-depth complex literary texts, it did result in an almost explosive flourishing of cultural life, reading, and bookselling. This involved the intense circulation of some literary texts, especially poetry, as part of the political struggles.

If optimism and unity prevailed in our meeting in March 2011, soon afterwards a more antagonistic struggle between different movements shifted the mood. Celebratory writing about the victory of the magnificent revolution began to sound suspect in the ears of those who insisted that the wrong people were winning and that the revolution must continue. This split reached its dramatic peak at the end of November 2011 in the Mohamed Mahmoud Street uprising against military rule. It was the formative event of the so-called revolutionary current that, in explicit opposition to the pragmatic electoral policies of Isla- 
mist parties at the time, turned revolution itself into its main aim (Schielke 2015; Ryzova 2019). A shared spirit of struggle and rejection was the mood.

\section{Reading Amal Dunqul in 2011}

Among those who joined that revolutionary current was the previously mentioned satirical author Amr Ezz Eldeen, who had recently moved to Cairo to work as a teacher of Arabic for non-native speakers. One evening at the end of November 2011, I ran into him on Tahrir Square in the aftermath of the street battles of Mohamed Mahmoud Street. Amr and his friends were having a tea break on one of the green spaces in the square late one evening, and they had one book with them: the collected works of the poet Amal Dunqul (1940-1983), which they were reciting and discussing. Dark, bold, and determined, the poems of Dunqul seemed to have been written just for that moment.

Yet Dunqul, a communist, militant nationalist, and bohemian who cultivated the attitude of principled opposition in his life and literary work (Elreweny 1992), had himself expressed a rather sceptical vision about the power of poetry to make a difference. In 1975, he published the poem From the papers of Abu Nuwas (Min awraq Abi Nuwas) in which he let the Abbasid-era poet Abu Nuwas (c. 750-814; see Kennedy 2007) speak about the asymmetry between the power of the word and the power of money and violence. In one part of the long poem, Dunqul, who was famous for his use of Arabic, Islamic, Roman, and Hellenic history and myths, relates Islam's most powerful story of martyrdom: the massacre of the Prophet Muhammad's grandson al-Husayn and his followers in an ambush by the Omayad caliph Yazid ibn Mu'awiya:

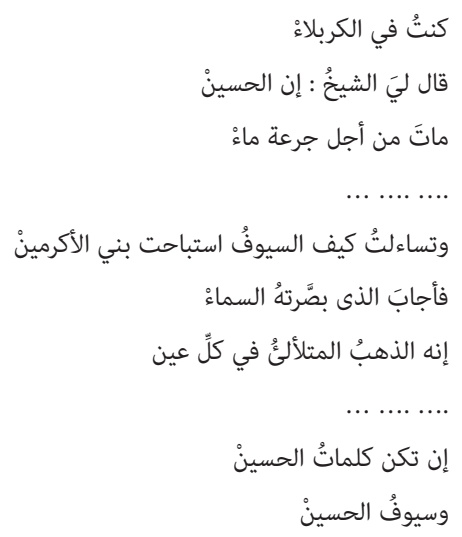




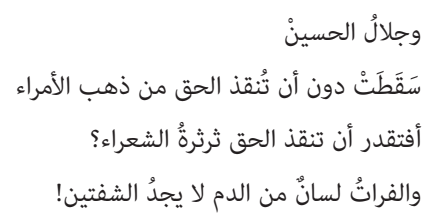

I was in Karbala

The old man told me: al-Husayn

died for the sake of a mouthful of water

.........

I asked how the swords could prey on the noblest family

The one whom heaven had gifted with sight answered

that it was the gold that glittered in every eye

If the words of al-Husayn

and the swords of al-Husayn

and the majesty of al-Husayn

fell without saving the truth from the gold of the princes

How could the truth be saved by the babbling of poets?

While the Euphrat is a tongue of blood that does not find the lips!

(Dunqul 2005, 334; my translation). ${ }^{1}$

Of course poetry cannot change the world. Poetry is about the work of metaphors and symbols, the rhythm and music of language, and the play of mind, moods, and meanings. How could it possibly make any difference in a world where the power of the strongest prevails, where guns and drones speak loudest, and where brainwashing by mass media and blackmail by secret police are the most compelling forms of the spoken and written word?

And yet Amal Dunqul was not deterred from writing poetry that was strongly committed to national and revolutionary struggle. He left behind a powerful and innovative oeuvre that glorifies uncompromising struggle and combines it with a deep pessimism. In 1962, in the early years of his career, his poem Spartacus' Last Words (Kalimat Sbartakus al-akhira) caught the tragedy of revolutionary struggle in a way that has lost nothing of its validity today. Its opening lines take up the Biblical and Qur'anic story of Satan's fall from grace, and turn it into a symbol of tragic heroism:

1 Most of Dunqul's poetry is freely available online, as are many original recitations by the author. 


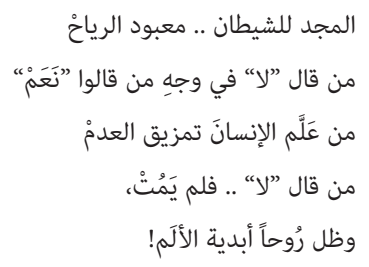

Glory to Satan, god of the winds

Who said 'no' to the face of those who said 'yes'

who taught Man to tear apart nothingness

He who said 'no', thus did not die

And remained a soul eternally in pain

(Dunqul 2005: 1; English by Suneela Mubayi 2012)

In 1976, still quite some time before Sadat's famous visit to Jerusalem and the Camp David treaties, Amal Dunqul took the murder of the pre-Islamic Arabian tribal leader Kulayb in $494 \mathrm{CE}$, which resulted in the forty-years-long Basus War (see Hoyland 2001) as the foil for Don't Reconcile (La tusalih), one of the most powerful anti-peace poems ever written. This is its beginning:

Don't reconcile

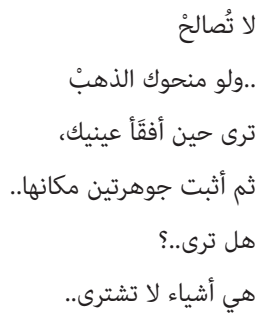

... even if they granted you gold

What if I gouged out your eyes

and replaced them by jewels...

Will you see?

These things cannot be bought...

(Dunqul 2005: 347; my translation)2

For a long time, Dunqul's work was appreciated only in small leftist and intellectual circles. His poems, written in modernist taf'ila, free verse with a recognisable

2 For other translations, see, e.g., Roters (2011), Hegazy (2007). 
rhythm, are not as easily adaptable to be sung and memorised as popular colloquial poetry is. Strongly oppositional in content, they were also a thorn in the side of the Egyptian authorities. They were not forbidden, but they rarely received reviews or other mentions in state-controlled media. The situation changed quite suddenly with the outbreak of the 25 January revolution, which was accompanied by a revival of politically committed leftist poetry from the 1960s and 1970s (Colla 2020). Ahmed Fouad Negm's (1929-2013) witty and rude colloquial poems and songs in particular gained enormous popularity and circulation, and a few of Amal Dunqul's verses entered the corpus of revolutionary citations. While Negm's poetry with its commitment to colloquial orality was more suitable for songs and slogans, Dunqul's poetry was more likely to find its ways to graffiti, discussion circles, and quotes on social media (Roters 2011; Nicoarea 2013).

In autumn 2010, a graffiti artist sprayed a passage from Spartacus' Last Words on the seafront boulevard in Alexandria in protest against the expectation that Hosni Mubarak's son Gamal would soon follow in his footsteps:

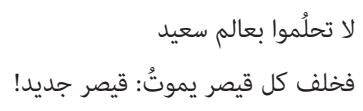

Do not dream of a happy world

For behind every Caesar who dies, there is a new Caesar

(Dunqul 2005, 93; my translation)

As citations from Dunqul's works circulated (see images 14 and 15), they also gained independence from their original political context. In 2011 and 2012, the line 'Don't reconcile' - originally written in anticipation of a peace treaty with Israel - became a widely cited expression of determined struggle against the direct military rule by the Supreme Council of the Armed Forces, and was sprayed on many walls as a call to not give in and to make no compromises. 'We are those who said no' became the title of a social media group established in 2011 in reference to the constitutional referendum of March 2011. ${ }^{3}$ The opening lines of Spartacus' Last Words were sometimes cited (although often without mentioning Satan) by proponents of a no vote in the constitutional referendum in December 2012. In short, Amal Dunqul became a key poetic voice of principled rejection in 2011 and its aftermath.

3 Ihna illi qulna la', https://www.facebook.com/No4everythingisWrong. 


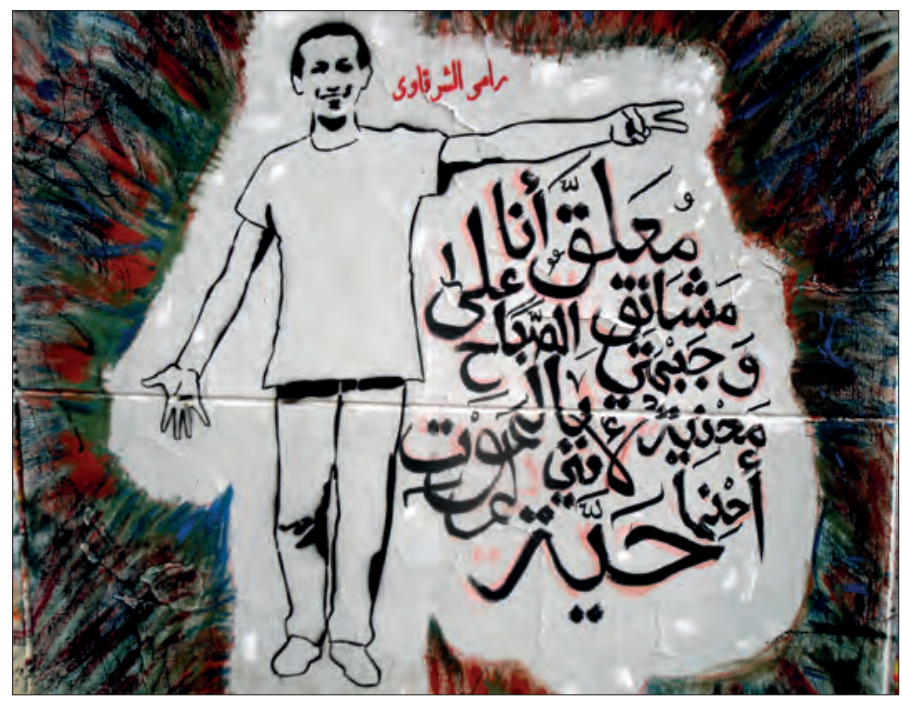

Image 14: Graffiti in downtown Cairo featuring Rami al-Sharqawi, who was killed by security forces during demonstrations at the Council of Ministers on 17 December 2011, with a passage from Spartacus' Last Words: 'I hang from the morning's gallows / My forehead lowered by death / Because alive, I did not lower it!' (translation by Suneela Mubayi 2012). Photo by Shady Basiony Marei, April 2012. Reproduced with permission.

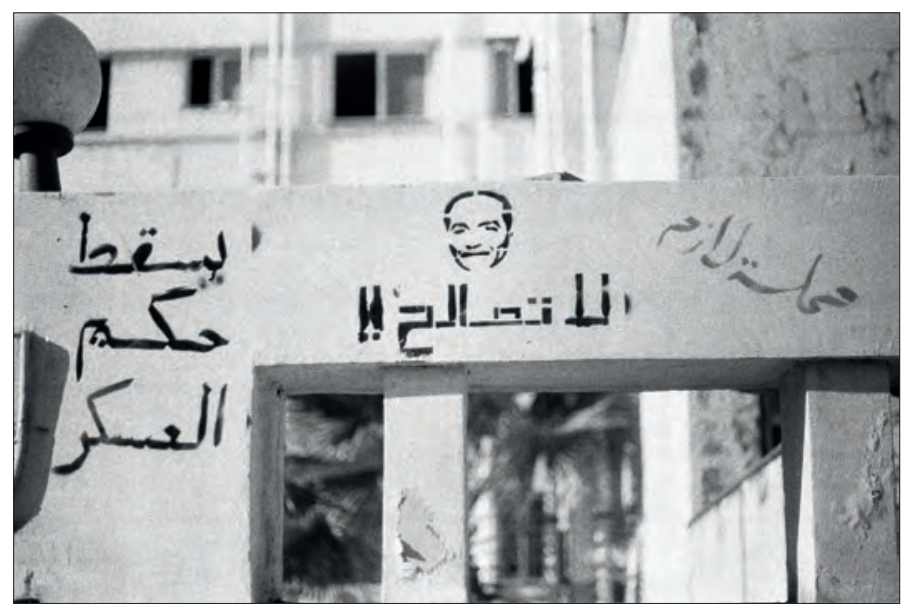

Image 15: Graffiti outside Alexandria University, photographed in October 2012, showing a portrait of Field Marshal Hussein Tantawi and the words 'Don't reconcile' (below the portrait in the middle) and 'Down with military rule' (on the left). It is signed (on the right) by 'the We Must campaign' (Hamlat Lazem), a small and short-lived leftist/liberal campaign. 
Of course poetry does not change the world, and yet the sudden popularity and timeliness of Amal Dunqul's work in 2011 show that the question about poetry and change needs to be asked - the more so since many Egyptian poets and writers have been asking the same question. They have some interesting answers to offer.

\section{The question must be posed in a different way}

Poetry is the most popular genre of literature in the Arabic speaking world. People who may never have read a novel in their life nevertheless often memorise some lines of poetry, and may have composed some themselves. While the market and readership of books of fiction and poetry are small, popular genres of Arabic poetry enjoy wider circulation because they remain strongly grounded in the spoken word - and therefore are also often circulated through audiovisual media (see, e.g., Miller 2007; Colla 2020). During the time of our fieldwork, streaming platforms YouTube and Soundcloud, rather than books, were the main channels of distribution for mass-audience colloquial poetry. This is reflected in the way most current Arabic poetry continues to rely on rhyme and meter. More experimental styles of free-verse poetry exist and are produced and consumed in more dedicated literary circles, but poetry as a popular art remains strongly committed to a recognisable rhythm and language with a musical quality. Obviously, poetry has a strong link with music: pre-Islamic poetry and song were inseparable (Adonis 1990). Today, the borders between poetry and song are hazy, and some of the poets we met in Alexandria had also been successful as songwriters. But there is, of course, a material difference between the written and the spoken word, and some poems are better for singing, while others are better suited for reading and graffiti.

Poetry in the Arabic language has a long and magnificent history (Khouri 1971; Badawi 1975; Jayyusi 1977; Adonis 1990; Kennedy 2007). The oldest known Arabic poetry was in circulation long before the rise of Islam and was collected in written form in the first centuries of Islam. This 'poetry of the age of ignorance' (al-shi'r al-jahili; Al-Jundi 1991) remains the ultimate standard of Arabic poetic expression today, and an Arabic literary education invariably begins with those first poets, then proceeding through the establishment of meters and genres, theories of rhetoric and poetics, the works of classical poets across centuries - and finally perhaps contemporary poetry. The poetry that is written or spoken in a place such as Egypt today, however, is different from that heritage. Contemporary poems are often short, and they seldom use the double verse of classical Arabic 
poetry. They are also often strongly subjective, moved by a romantic theory of the author expressing her or his authentic self (see Chapters 1 and 8) - in contrast to classical Arabic poetry in which eloquence of expression was crucial while originality of meaning was not. An ever-larger part of contemporary poetry is in colloquial Egyptian Arabic, which differs from Classical Arabic in morphology and syntax, and also in rhetorical registers. As a result, there has emerged a divide between Classical Arabic as the language for more highbrow, more serious, and either decidedly conservative or decidedly avant-garde poetry (more about those in Chapters 7 and 8), and Egyptian Arabic as the language of more popular, more humorous, and more down-to-earth poetry. There are interesting exceptions to this distinction, an example being free verse in Egyptian Arabic, which was launched by a group of young writers in the 1990s and is associated with an avantgardist literary aesthetic.

In any case, poetry has a strong presence in life, and many people quote it to express their feelings, to argue a point, or to make sense of a situation. On occasion, poetry has become intertwined with the language of political conflict and dissent.

In the winter of 2010-2011 and during the following spring and summer, a series of revolutionary uprisings shook the Arab world. They marked the beginning of a stormy season of political confrontations, chaotic shifts of mood and coalitions, and general societal turmoil. The early enthusiastic days were a poetic moment in two senses. First, poetic verses turned into chants and slogans were an important way to mobilise the uprisings and to express their demands (Colla 2012). Second, there was a poetic quality to the moment of uprising itself, which I tried to describe in an earlier work:

\footnotetext{
A revolution is in itself a poetic event insofar as it is about taking the ordinary things, otherwise evident and transparent like the words of prose, and playing with them, wondering about them, not taking them for granted, putting them together in a new configuration. [...] If in ordinary days the work of fantasy precedes action by opening the space to think of alternatives, in the time of a revolution, action runs ahead of imagination and forms it. This was the original revolutionary moment: the birth of a sense that something to date unimaginable is in the process of being realised. (Schielke 2015: 180)
}

It all turned unimaginably more complicated, frustrating, and violent in the course of the following years. Meanwhile, the catastrophic failure of almost all those revolutions (with the potential exception of Tunisia) is now evident. The fantastic quality of those days seems, in hindsight, to belong to the field of fantasy. Or - a more disturbing thought - the fantastic quality of those days may in some way have contributed to the bloody mess that followed. 
Writing about the poetry that was recited and produced during the first days of the Egyptian revolution, Lewis Sanders IV and Mark Visonà (2012) in rather celebratory tone describe poetry as 'the soul of Tahrir' and grant it the power to give shape and name to what was emerging in that moment. They also point out that the nation and the body of 'the people' (al-sha ' $b$ ) were at the heart of those poems that reflected and gave direction to a vision of the uprising in terms of national liberation and unity. It was an ambiguous direction though, and the openness of the claim to speak in the name of 'the people' made it available for revolutionary and counter-revolutionary slogans alike (Colla 2012). This nationalist grounding of the uprising - and its ambiguity - at first went unnoticed by many academics and media observers, who were paying perhaps too much attention to the Islamists, who at the time appeared to be the uprising's main winners. But religious politics, rather than uniting Egyptians, turned out to be so divisive that it provided the occasion for a counter-revolution in 2013 that was emphatically and explicitly framed by its supporters in nationalist terms as 'the people' against 'the terrorists'. The spirit of heightened nationalism and patriotic unity that was shaped in Tahrir in 2011 became, in 2013, the ground of faith for a new military regime that entered a violent confrontation to eradicate its Islamist contenders.

Many of the prominent literati of the capital emphatically sided with this nationalist turn, and in different ways supported the new military leadership and the brutal suppression of its opponents in the name of a 'war against terror'. Novelists such as Alaa El-Aswany and Sonallah Ibrahim and poets such as Abdel Rahman el-Abnudi and Ahmed Fouad Negm, who in 2011 had spoken out loud for the revolution, spoke out after summer 2013 for what they believed was a revolutionary cleansing of Egypt from anti-patriotic terrorist elements (CNN Arabic 2013; Lindsey 2013; Negm 2013; el-Abnudi 2014; Azimi 2014). On the other side of the struggle, less prominent poets sympathetic with the cause of the Muslim Brotherhood produced texts that gave words to their struggle, and sometimes also expressed their frustration about so many people turning into what they saw as 'slaves of the military boot'. Yet others took an outsider position, supporting neither military rule nor the Muslim Brotherhood, frustrated and marginalised in face of a destructive circle of confrontation and violence. Many poets who were associated with this third stance - notably the popular colloquial poet Mustafa Ibrahim (2013), whose fame was to a major degree linked with his participation in demonstrations and his poetry that spoke from within the crowd of protesters fell into a lengthy period of silence or stopped addressing political topics, leaving 
the stage of critical commentary to comedians such as Bassem Youssef and satirical writers such as Belal Fadl, who in turn were soon forced into exile. ${ }^{4}$

So when we ask whether poetry can change the world, it is a question that concerns an ambiguous change. There is no escape to the arrogant confidence of Jean-Paul Sartre (1949: 63-64) who in his call for engaged literature claimed that of course good literature and good cause were united. The question needs to be asked in a different way. What kind of relationship could the poetic word have with this world we live in?

Before 2011, a division between different ideals of authorship had gradually emerged. The twentieth-century modernist figure of the 'conscience of the nation' who was at once independent and committed to societal improvement and a tradition of $a d a b$ (meaning both the cultivation of fine manners as well as literature in general, see Chapter 2; Jacquemond 2008: 10) faced increasing competition from a figure who was at once more ordinary, and more explicitly an outsider: a critical observer and explorer who stood in a tradition of literary imagination as a site of exploration and experimentation (Kennedy 2007). This split (which we discuss in more detail in Chapters 2 and 3) has a longer history (Pepe 2019b) and its spread has been far from even across milieus. And yet in 2011, it was for a moment thoroughly destabilised.

In this moment, interesting conversations took place in circles that could be described as the avant-garde wing of a conservative modernist milieu. Among people we met in these circles, questions about autonomous text and literary commitment, and roles and ethics of authorship appeared less as markers of positionality in the literary field and more as open questions for debate. In encounters at cafés in the East of the City, far from the internationally connected scenes and independent institutions of the downtown, we conversed with men (and one woman) who before 2011 had already been aesthetically and politically in an inbetween position: between public institutions and politically critical stances, between openness to literary exploration and commitment to traditions, and between political leanings ranging from Islamist to leftist. They often brought together both ends of these tensions in idiosyncratic combinations. Their perspective was grounded in a wider section of the society that played a key role in the revolutionary process: a vast social class of urban inhabitants who are exclu-

4 Pioneer of a style of satirical writing that became popular for a short time before 2011, Belal Fadl (e.g. 2005) was an important third-current voice from summer 2013 until January 2014 through his column in the daily newspaper Shorouk, although his influence was more limited than that of the TV comedian Bassem Youssef (see Fadl 2014; Mada Masr 2014). For an overview of Belal Fadl's columns in Arabic, see http://www.shorouknews.com/columns/BilalFadl. 
ded from the status and habitus of the bourgeois classes (often euphemistically called 'middle classes'), but who by the means of their education and their work as civil servants or salaried workers nevertheless manage to aspire, work, and live above the poverty line.

In a situation where questions about didactic purpose and poetic licence appeared more open ended than otherwise, many of the writers we met in eastern Alexandria in those days found themselves compelled to reflect on the relationship that literary writing might have with conflicts and transformations, be they political, social, spiritual, or intimate. One such discussion took place among a group of writers gathered in a café in the eastern outskirts of Alexandria; and it was Amal Dunqul in particular whose work they frequently mentioned.

\section{A discussion with poets, where an answer begins to take shape}

In October 2011, we met for a second time with a circle of friends around the poet Kamal Ali Mahdy in the east of Alexandria. All of them were male schoolteachers in their late thirties or forties. (The first of our meetings with them is featured in Chapter 1.) In those days, they used to gather in the small garden of a café on the outskirts of the low-income neighbourhood of Abu Kharouf to discuss politics, poetry, and life. Most of them were active writers, and some of them could claim a name in the literary circles of the city. Literature was for them not a profession but a passion, which they pursued as a sort of parallel life next to their ordinary lives as schoolteachers and fathers.

Our second meeting brought together the writers Kamal Ali Mahdy, Muhammad Mahmoud Mousa, Ashraf Dossouki Ali, and Hamdy Mosa, ${ }^{5}$ and additionally N., who described himself as a passionate reader but not a writer, and Mukhtar and myself. This was a time when the future course of the Egyptian revolution was still unclear, when continued optimism was becoming mixed with increasing frustration and pessimism, and when many of the political divisions that would later pit people against each other had not yet taken full shape. All the men in the circle saw themselves as supporters of the revolution, but in the following years they have taken different paths in political matters.

The original topic of the discussion was poets' search for fame and immortality (continuing our discussion at the previous meeting that is featured in Chapter

5 For some of their published works, see Ali (2007, 2008, 2015); Mahdy (2005, 2007, 2014); Mosa (2012a, 2012b). 
1), but the topic shifted when the effect of two poets on the Egyptian revolution was mentioned. One was Amal Dunqul, the other the Tunisian Abu al-Qasim alShabbi (1909-1934) whose poem, The Will to Live (Iradat al-hayah), originally written in the context of an emerging Tunisian national movement, had become something of a refrain of the revolutions in Tunisia and Egypt.

In a meeting a week earlier, the poet Kamal Ali Mahdy had mentioned that Amal Dunqul had 'shaken up' society with his poetry and with provocative verses such as 'Glory to Satan' and 'Don't Reconcile'. Now, Kamal took up Amal Dunqul's poetry again to point out that good poetry can gain new life and relevance decades after it was written. This resulted in a discussion about poetry's capacity to move people and to change the world.

It was a long discussion, and I quote it almost in its entirety. Anthropologists often translate their ethnographic knowledge into the academic jargon that is in fashion and explain it with theories that are circulated by their academic peers. And yet we usually owe the best of our ideas not to the theories we read elsewhere, but to encounters in the field with people who have good theories of their own about their own situation. That evening in the café was one such encounter of inspiring conversation and generous sharing of ideas, and it provided two interesting theories.

Kamal: The lasting genius of Amal Dunqul is that he shook up society and made a change in it. That is the genius that gave his work permanence. It is the genius of something nobody else had done, shaking up Egyptian society. ...

Muhammad: I believe that poetry is like different seeds. Every seed sprouts and grows, flourishes and thrives in a specific soil. So when a poem finds specific conditions that suit it, it flourishes. When did the poetry of Amal Dunqul become famous? In the 25 January revolution, because he was a revolutionary. And a strong romantic poem can become famous if the society comes to a rest and the material conditions of life improve; then the poems in circulation will be romantic poems. Why is Amal Dunqul famous now? Why not five or six years ago? Why do we talk about him now? Because of the 25 January revolution.

N.: When Abu al-Qasim al-Shabbi said:

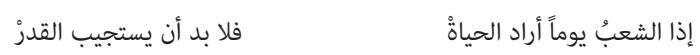

If one day the people will to live

Then Fate must an answer give ${ }^{6}$

6 Abu al-Qasim al-Shabbi, Iradat al-hayah (The will to live), English translation by Sanders and Visonà 2012: 229. This poem, which is cited in the Tunisian national anthem, is the source of the slogan الشعب يريد إسقاط النظام 'The people want the toppling of the regime', which follows the same metre as the poem and was originally coined in Tunisia in December 2010. It has been repeated 
in the period of the French occupation [of Tunisia], that verse fitted very well. Then a period followed when it didn't fit. In the current period it fits very well again. So there does not need to be permanence, it depends on its period. Look and you see: the verse changes the world. Why? In this atmosphere, people are affected by it. They want change. They find this verse and are affected by it.

Muhammad: If the necessary conditions are there and the society rises up in revolution, then you will find the poetry of Amal Dunqul revived.

Samuli: Do you mean that the revolution is an occasion to read Amal Dunqul, but that Amal Dunqul did not cause the revolution?

Muhammad: No, he is not a cause of the revolution. But his poems were written in a revolutionary state of mind. So every time the people rise up in revolt, they will find a poem by Amal Dunqul that suits them. Otherwise, where was Amal Dunqul for the past thirty years when Hosni Mubarak ruled and there was no revolution? Nobody mentioned Amal Dunqul then.

Kamal: I mean that Amal Dunqul as a contemporary of the defeat of 1967 said something that shook up society. ${ }^{7}$ He refused the reality. I don't mean that he was only protesting against the defeat of 1967 ... If he had lived in the days of the revolution [of the Free Officers] in 1952, he might have been against the revolution itself. And if he had lived before 1952 [during the monarchy] he might have been a revolutionary against the king, and so on. ... His genius is in the way he takes up rejection, and convinces us to join him in rejection, to go along with him in that direction.

Hamdy: I support what Kamal said, but I want to take it to another direction. The poet is an anarchist and a buffoon. He strives to establish himself and his character through difference and opposition. Amal did that. He demolished the traditional structure of poems and strove for a different vision altogether, new idea and new technique. Through difference and opposition he wants to say: 'I'm ingeniously different from the others.' With his genius he reached a different level and delighted the reader with his stance of difference. ... But poetry does not change the reality of society. I even say that the Qur'an itself does not make a change. The Sublime and Exalted God is the one who makes a change. Let me tell you something. When I sit in a café and they play recitation of the Qur'an on the loudspeakers, I'm well aware of the meaning of the verses, and I'm aware of commanding the right and forbidding the wrong - yet despite knowing all that I continue doing whatever I'm doing. Therefore the noble Qur'an did not change me because the will to change by the Sublime and Exalted God was not there. And that is the highest book of all.

N.: That you didn't change is not the Qur'an's fault. But it does change others.

in all uprisings in the Arab world since 2011. For a history of the poem's different readings and uses, see Colla (2012).

7 In 1967, the Arab armies of Egypt, Syria, and Jordan were defeated by Israel in a humiliating manner in the Six-Day War. This event became central to much of Amal Dunqul's literary work. 
Hamdy: It changes others because it is accordance with the will of God.

N.: But everything is in accordance with the will of God. ${ }^{8}$ If a car hit me now, would it not be in accordance with His will?

Hamdy: Look, maybe Abu al-Qasim al-Shabbi didn’t originally speak his verse as a political protest as we imagine. Maybe he was addressing a particular issue of social injustice. But when a revolution occurs, there is what rhetoric calls speech in accordance with the circumstance. In the circumstances of a specific time, that verse is in accordance with a specific mental state. Therefore it gained a dimension that wasn't imagined by Abu al-Qasim alShabbi.

N.: A question if I may. Why did the Prophet, peace and blessings be upon him, include one like Hassan ibn Thabit in the work of $d a^{c} w a$ ? $^{9}$ Hassan was just a poet, what did he change in the Islamic society so that the Prophet included him?

At this point, N. and Hamdy entered a detailed debate about what the role of poets was for spreading Islam in the age of the Prophet. Hamdy maintained that it was merely to react to poetic attacks ( $h i j a$ ') against the Prophet, while N. detailed examples in which poets had compelled polytheists to recognise the supremacy of Islam. This prompted Hamdy to clarify his argument:

I say that something changes when it is in accordance with the will of God. I did not rule out the role of poetry in shaping life. But in light of the current culture of society, it is a relative change in the relation of one to a million.

\section{N.: Currently or generally?}

Hamdy: For a very long time. I gave you an example. The most eloquent books in existence are the Qur'an and the Bible, that is, the divinely revealed books. They are the highest in poetic expression and wisdom. But the increase in the numbers of Muslims, Christians, and Jews is only proportional to the increase in the population of the world.

Ashraf Dossouky Ali: Maybe Hamdy raised an issue that belongs to the invisible realm (ghayb), which is beyond my power, and it is a different topic. But to get back to the discussion about creative production ( $i b d a$ ), one of the elements of creative production is asala (originality, authenticity), and the other is fluency and skill. ... If you are an original (asil) poet or writer and you master your technique and your talent, and possess a vision, then you can initiate a change, and you can do it across time and space. There is a poet whose

8 Ashraf is making implicit use here of a Sunni Muslim theology of freedom and destiny according to which humans are free to act, but they act out the predestined will of God. According to this theology, human intention, cause, and effect are real, but they can only occur in accordance with the will of God, as Hamdy agrees in the following course of the discussion.

9 For his biography and poetry, see Hassan ibn Thabit (1994). 
capacity is limited to making a change in the framework of his tribe, or his nation in the modern era; and there is another poet who can claim to be universal, or global, and who can change others in a radical way. A radical change does not mean that it involves everybody. We say that the Egyptian people all went out in the 25 January revolution. But that does not mean 80 million Egyptians did it. Those who had a concern for the problem of change did. ... If you are an original poet or writer, you are capable of addressing the supreme shared grounds of humanity. When I write a poem and it reaches a greater number of people, when it reaches the Egyptian, the European, the American, this means that I have been able to touch a shared human element that we all have, because we all descend from Adam. ... As for a poet who does not initiate a change, he is one who only expresses his own self, his internal problems. But when he speaks about a problem that touches others, this means he is capable of reaching the shared ground of humanity. ${ }^{10}$

N.: That's the question I want to ask. Why are poets right now unable to change anything? Is it the poetry's fault? Or is it the poets' fault?

Muhammad: It's society's fault, a society that does not enable people to read. And politics has participated in alienating society from reading. The poet has ended up writing for himself.

N.: Our society is useless. How else could someone like Hisham Al-Gakh have made it to fame? ${ }^{11}$

Mukhtar: Hisham Al-Gakh is merely a vocal phenomenon, nothing more.

N.: But he made it.

I have given this discussion so much space because the four poets provide key theoretical answers to the question that frames this chapter. The discussion boils down essentially to two theoretical answers. According to one theory, which is argued for in different nuances by Muhammad Mousa and Hamdy Mosa, we make recourse to words and ideas that convey the situation in which we are. If there is a revolution, then people revive revolutionary poetry to express their situation, but poetry itself has no power to initiate a revolution. Hamdy goes so far as to deny

10 With this argument, Ashraf follows the mainstream romantic theory of authorship that foregrounds the creativity and subjectivity of the author in combination with a skill based on traditions and canons, and the capacity to reach an audience. For more on varieties of romantic authorship, see Chapters 1 and 8.

11 Some years before 2011, Hisham Al-Gakh became very famous with a poet persona that displayed Upper Egyptian rootedness, and very straightforward colloquial poetry that addresses the worries and frustrations of ordinary Egyptians. Poets who moved in dedicated literary circles during our fieldwork commonly loved to hate Hisham al-Gakh and his populist style. For a translation of one of his poems, see Sanders and Visonà (2012: 27-28). 
that divine revelations have the power to change people's minds. Such power, he argues, is God's alone and therefore beyond any worldly causality. Later the same evening, he added that poetry can affect individuals through the power of aesthetic pleasure, but that whatever change this may involve remains entirely on the individual level.

According to the other theory, which is argued more cautiously by Kamal Ali Mahdy and more strongly by N. and Ashraf Dossouki Ali, poetry does have the power to provide people with ways to feel and act. According to Kamal, Amal Dunqul's poetry unsettled values that have been taken for granted and also helped to establish the attitude of rejection as an affect and a moral virtue - something that was instrumental for the revolutionary process (see Schielke 2015: 191-215). N. and Ashraf go further and argue that poems can have the power to generate emotions and ideas in its audiences, to make the world appear in a different shape, and thus to provide inspiration for different actions on the world - a view that is also echoed in many scholarly takes on aesthetics and politics (e.g. Rancière 2004; Badiou 2005; Van Nieuwkerk et al. 2016).

While the poets in the gathering disagreed about the theoretical problem of the power and powerlessness of words, they unanimously agreed that in practice, poetry has less power than it should because people do not read and because only second-rate crap (such as the poetry of Hisham Al-Gakh) gains wide popular appeal. This is a characteristic predicament of all artistic and creative production: the more nuanced and sophisticated the creative production, the more it becomes a distinctive property of a dedicated and cultivated few and the less likely that it will reach wider audiences. Especially in Egypt, there is a stunning gap between the social and moral authority writers claim (and sometimes gain) and the actual readership of literary works (Jacquemond 2008: 6). Poetry that can shake up that which is taken for granted can only do so among those whom it reaches in the first place and who are interested in such play of mind. There are exceptions, however - rare occurrences such as the 25 January revolution when the avantgarde work of Amal Dunqul suddenly gained a wider audience. But even then, it was one-liners that reached public consciousness, not full-length poems.

\section{Consequences}

Inspired by this discussion, during the following days Mukhtar developed a theory to unite these two theories, to show how literary fantasy might indeed make a difference and why that power was always limited. The outcome was what he describes as a dialectical triangle of fantasy, dreams, and choices. In 
this theory, fantasy (khayal, here in the sense of an imagination that is conscious about the non-reality of the imagined) is a space of freedom where one can imagine and explore ideas without having to consider their practical possibility or feasibility. One is not, however, free to have unlimited fantasies. This is therefore not a liberal theory in which people just need to dare to imagine something in order to pursue it. On the contrary, the scope of the imaginary is a scarce resource that is available to different people in different degrees. Fantasy, Mukhtar argues, is in turn linked with dreams (ahlam, here in the sense of imaginations that are linked with the expectation that they can and need to be realised). What at the level of fantasy was a play of mind, can be an ambition and a plan as a dream. Such dreams can be the ground of choices that people make and ambitions they pursue, that is, concrete actions that have a material effect and possibly change reality in one way or another. And that reality, in turn, is the ground that determines the scope of dreams and fantasies. But it is an unpredictable process, Mukhtar points out: the revolution was in part marked by the way some people were able to turn impossible fantasies into concrete actions, but these actions are not conclusive. They initiate a new circle of choices, dreams, and fantasy, and as long as the circle is not complete, we lack the scope of imagination to anticipate its consequences.

In light of this theory, it becomes clear that the question whether poetry can change the world was posed in a misleading way for two reasons. First, poetry is not separate from the world to start with, and therefore cannot have external causality. Instead, it is part of the world as it changes, with fantasies becoming the ground of dreams and actions, and actions and experiences feeding and limiting the scope of the imaginable. Fantasy, too, is a scarce resource. Second, the question has been posed in too megalomanic a fashion, as if only great and dramatic change would count. Such megalomania was compelling in Egypt in 2011. Talk about 'change' (taghyir) was in the air, and it did not mean just any change. It meant sweeping, fundamental, holistic transformation of humanity, politics, and society. This grand vision of change neglects processes where some things change but only for a handful of people; and it also neglects the possibility of change being destructive.

More often than not, the productive relationship of fantasies, dreams, and actions is limited to intimate, personal change and makes little or no difference to wider relations of power. As Amal Dunqul reminds us in From the Papers of Abu Nuwas, the gold of princes remains far more powerful than the babbling of poets. This is how Mukhtar saw the situation more than two years later when he (in a written message) shared with me his bitter frustration about the course of the events: 


\begin{abstract}
Poets only make a change in their imaginary world that is parallel to the real world of frustration. There is no real change happening. If anything changes it is through force, deception, and manipulation. The dreamers and poets are simply used, their sweet words are spread to beautify the picture. Change is made by those with realistic interests. The poets and dreamers spearhead the change in a dream world that has no relationship with the real world, but they are being used [by the powerful for political ends]. The Muslim Brotherhood never liked Amal Dunqul. The revolutionaries never stopped dreaming. In no country has the military ever understood poetry and dreams.
\end{abstract}

This is the gist of Mukhtar's sceptical revision of his theory in January 2014: those who actually have the power to make a difference do not care about poetry, but they do know how to exploit sweet words to beautify their crimes. The original, authentic change that is involved in poetry only reaches a few crazy dreamers and remains in a parallel world.

This is, in fact, a widespread view among poets and writers I have spoken with, many of whom have always been rather sceptical about the idea that their writing could make a difference in society. However, they do think that writing can make a difference - for the writer. As we argued in Chapter 3, those most tangibly changed by literature are the literati themselves, along with those who search out their company because they are drawn to the world they embody. And even then, the change is seldom a straightforward realisation of an intended transformation.

The poet Shaymaa Bakr (featured in Chapter 3, and loosely connected with people in the Hala group at the time of our research) was especially explicit about the ideological, literary, and institutional in-betweenness that characterised many among the poets we met in the East of the City. A declared Islamic internationalist at the time, her literary aesthetics stood in the tradition of the twentiethcentury leftist modernism of Amal Dunqul and his peers. Shaymaa Bakr as a poet displayed an overall critical attitude of nonconformity ('I'm against everything' she said on one occasion), which distinguished her from those writers with Islamic leanings who strove to contribute to moral and political projects of reform or revolution (see Chapter 8). Between 2011 and 2012, Shaymaa Bakr recorded her sceptical vision of the revolutionary dream of change in her poem I Say (Aqul ana), which she described to us as a 'rebellion against rebellion'. The following is my translation of a short passage from her much longer poem:

$$
\text { كان لابد للشاة أن ترفض أن نقبض الريحَ }
$$




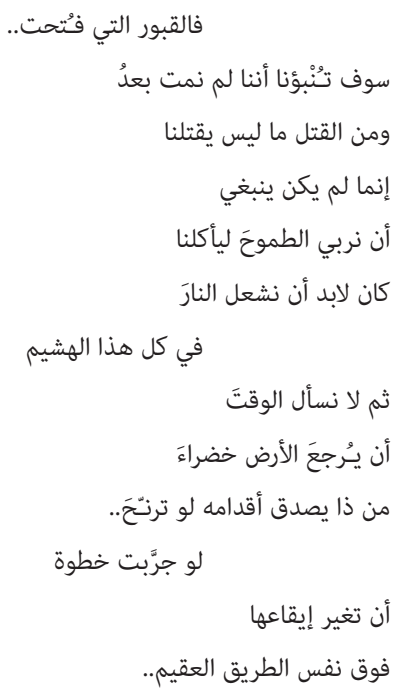

We had to grab for the wind

The sheep had to reject being skinned

after it was slaughtered

Brothers of ours had to die ...

so that the open graves ...

can promise to us that we haven't died yet

that there is killing that does not kill us

But we should not have

raised our ambition so that it can devour us

We had to set fire

$$
\text { to all the dry wood }
$$

without afterward demanding from time

that it may turn the earth green again

Who would trust his feet if he staggered

$$
\text { if one step }
$$

tried to change its pace

on the same futile road...

I Say is an interesting vision of the dilemma of those Egyptian revolutionaries who according to Mukhtar 'never stopped dreaming', who spearheaded the idea of change, contributed to a political rupture, but failed to realise any of their aims 
and ends. Shaymaa Bakr points out that the problem is not just that they were defeated. More gravely, she tells us, their vision of radical change created a struggle that is structured so that it cannot be won. We set the dry wood on fire and expect earth to turn green again. We try to change the pace of our steps, but we are still on the same road. The revolutionary dreamers who indeed were inspired by crazy fantasies and unlikely dreams, transported some of those dreams from the closed circles of the dedicated few to the streets of Egypt. They failed, and yet they left their mark on history. Their struggle was effective but not liberating.

This is why I think it would be too optimistic to think of poetry and poets, literati, artists, and other dreamers and misfits as simply powerless when they face the sturdy power of oppression. It might even be too optimistic to think of them as useful idiots who unwittingly provide the powerful with an ideological cover. There is a third, more disturbing, possible consequence.

Kamal Ali Mahdy argued that Amal Dunqul taught Egyptians to consider rejection a virtue, a value in its own right in spite of likely or certain defeat. Only few Egyptians were actually affected, and the part played by Amal Dunqul's poetry may not have been particularly great. But those few belong to a radical political minority that, in the years following 2011, fashioned rejection as a political principle with important practical consequences. Their stance of a principled 'no' came with a radical vision of change as a value in itself, and implies a claim for uncompromising purity and struggle. They were by all counts far too weak to ever gain power, but they have been over and again able to stir the political situation and to disrupt the expected path of events. And more than once they have - sometimes unwittingly, sometimes quite willingly - helped more powerful forces to seize the day.

This is by no means unique to Egypt. Poetry, which includes songs and slogans derived from poems, has been strongly present in all the recent Arab uprisings. Some poetry - especially Abu al-Qasim al-Shabbi's The Will to Live - has travelled across the Arab world and become ingrained in the language of protest and revolt (see Colla 2012). At the same time, revolt has proved to have ambiguous consequences: it may be liberating; it is very likely to be destructive. This is not a new insight, of course. Albert Camus argued in 1951 that philosophical rebellion is a fundamental human trait that over time results in real revolutions. But, he adds, the problem is that revolutions are, by definition, murderous (Camus 1991).

Amal Dunqul promised eternal torment to those who say no. But it is not only the torment of futility and defeat that Mukhtar expressed. It is the torment of consequences. Not without reason did Dunqul set Don't Reconcile in the historical event of a murder that unleashed a war of vendetta so deep and bitter that it continued for forty years. As the principle of rejection has entered the daily life of Egypt, it has also become part of a world where compromises are considered 
treason and where confrontation appears as the only moral choice. Poetry, too, is complicit in the vicious circle of polarisation that hit Egypt after spring 2011.

Perhaps the most notable societal development in the wake of 25 January 2011 has been the intensification of processes of individualisation, fragmentation, and plurality in Egypt. In spite of heavy-handed efforts by the current regime to bring Egypt systematically under control in terms of cultural production and media, religious doctrines, and political and economic institutions alike, even now, ten years after the revolution, the enhanced fragmentation of ways and visions of life appears an accomplished reality in Egypt. The poetic and political affect of difference and rejection has been an unpredictable part of this process.

The role of literary imagination in societal and political transformations can thus be best understood as one of open-ended complicity. Any attempt to identify literature with resistance in a general manner is ultimately grounded in wishful thinking, or more precisely in a heavy-handedly selective vision that ignores all the literature and acts that do not fit into the kind of literature and resistance that one hopes to find. At the same time, literature is evidently not irrelevant. Otherwise, revolutions could do just fine without songs and slogans, and political and social movements could dispense with critical or inspirational stories.

Thinking of literature and literates as accomplices in societal and political developments of various kinds invites us to explore further specific themes and relations in which such complicity has been productive in the Alexandria of the 2010s. The exploration in the following chapters highlights two thematic complexes: urbanity (Chapters 5 and 6), and religious and spiritual commitments (Chapters 7 and 8). It begins with an outstanding and well-established theme in writings from Alexandria: the city itself. 